UDC 159.9

DOI: $10.17223 / 17267080 / 64 / 4$

\author{
Linkov Václav ${ }^{1}$, Zámečník Petr $^{2}$, Zaoral Aleš ${ }^{1}$ \\ ${ }^{I}$ CDV - Transport Research Centre (Brno, Czech Republic) \\ ${ }^{2}$ Palacký University, Department of Psychology
}

\title{
The Use of Driving Simulators in Psychological Research
}

\begin{abstract}
Driving simulators are important research tools that help to assess drivers' behavior. The article reviews which topics are studied with driving simulation in psychological journals, what kinds of driving simulation might be used, how many participants are necessary for such research to be publishable, and what kind of variables might be used. The text might be useful for psychologists when they plan to conduct research using a driving simulator.
\end{abstract}

Key words: driving simulator; psychology; stereotypes; distraction; cognitive overload.

Driving simulators are valuable research tools that allow studying the complex activity of driving. This text analyzes articles published in psychological journals where some kind of driving simulation has been used for psychological research. First, we described the content of the studies. Second, we analyzed the kind of technology used for the driving simulation, including the kind of information acquired and used in the driving simulation, and how large the samples were. Third, we demonstrated the differences between social psychological research and research in other branches of psychology, and we performed an analysis in which cases driving simulator were beneficial for the research.

We originally planned to analyze how driving simulators are used in personality and social psychology. We searched journals in the Web of Science category "Psychology, Social" for the words "driving simulator". The search resulted only in six articles that use driving simulation in research. We decided to add articles from other psychological areas into the analysis and searched for articles published in journals in Web of Science categories "Psychology, Experimental", "Psychology, Applied", and "Psychology, Multidisciplinary". We excluded articles that studied behavior under the influence of drugs or alcohol and studies about motion/simulator sickness, and we also did not include two studies from the same author about similar topics. This resulted in an additional 21 articles being included in the analyses below. If a study used driving simulation as one of multiple studies in the article, we refer only to the content and results of the overall study and not to the studies which did not use driving simulation.

\section{Research questions studied when employing driving simulators in psychological journals}

In the following paragraphs we describe the analysis of 27 articles. The first type of social psychological study that used a driving simulator concerns 
the influence of making stereotypes salient about driving behavior. Lambert et al. [1] found that for elderly drivers who read documents stating that elderly people are bad drivers and that reported accidents committed by elderly drivers (a stereotype threat condition), working memory capacity was positively related to following distance and negatively to brake reaction time. These effects were not observed for drivers who had not read such texts. Terror management theory postulates that people's awareness of one's own mortality leads to anxiety and terror, which people fight by pursuing the enhancement of their self-esteem. The mortality salience hypothesis states that making people aware of their own mortality leads to the enhancement of their effort for self-esteem. Taubman Ben-Ari et al. [2] used a driving simulator to test this hypothesis and showed that for participants for whom driving was important for their self-esteem, the making mortality salient led to faster driving. Making mortality salient had no effect for those for whom self-esteem driving was not important. If participants received positive feedback, the effect of mortality salience on the connection between driving speed and the importance of driving for self-esteem vanished.

Other types of studies search for the effect of some social influence, like peer influence or the self-concept, on driving. Jackson and Blackman [3] used a driving simulator to test the hypothesis that the higher cost of a possible accident, the lower the number of accidents is. When the penalty was higher, participants exceeded the speed limit less often. Fischer et al. [4] found that participants who watched risky scenes from movies (as compared to those who watched neutral scenes), had a larger number of accidents during a video game, accelerated up to $160 \mathrm{~km} / \mathrm{h}$ more quickly, needed less time to drive through a race course, and drove with higher maximum speed. Shepherd et al. [5] were interested in how social pressure influences risky driving behavior in a PlayStation driving game. Participants who heard pro-risky comments (e.g., "Go faster!") drove faster and had more accidents than those who heard neutral comments and anti-risky comments (e.g., "You're driving too fast."). Conner et al. [6] found that speeding correlates with the intention to speed and positive attitudes about speeding, the number of accidents in the last five years, the subjective norm about speeding, and the perceived behavioral control over speeding. Speeding correlates negatively with age, driving experience, the moral norm not to speed, and the anticipated regret for such behavior. Similar research has been conducted by Elliot, Armitage, and Baughan [7], who report that the mean speed in a simulator was negatively correlated with the attitude that speeding is bad, the negative subjective norm about speeding, and the intention to avoid speeding. Brewster et al. [8] found that people who write down their intention not to speed in certain situations speed less frequently in those situations than people who had written down their intention not to speed in a different situation or who did not write down any intention.

Phoning while driving reduces the driver's attention; however, this effect could be reduced if the communication partner has more information about the driver's actual situation. Janssen et al. [9] showed that when the sounds of driving or the sound of a driver's heartbeat are shared with the person who is on the 
other end of the call, the driver reacts more quickly to changes of speed of another leading car. If sounds are shared, callers have shorter talk segments. Gaspar et al. [10] found that collision risk during dangerous merging events was reduced when the partner with whom the driver was talking could see the same view as the driver.

A driving simulator might also be used to assess how people think about a car, specifically with the perception that it has human characteristics. Waytz et al. [11] let their participants drive either in a normal car or in a car which controlled its own steering and speed (agentic car). Some participants who drove the agentic car were told that car's name was Iris, it had a gender (female), and used a voice to speak to the participants while driving (anthropomorphic car). They thought the car could feel, anticipate, and was smarter in the anthropomorphic condition than in the agentic condition, and more in the agentic condition than in a normal condition. They trusted the car more in the anthropomorphic condition than in the agentic condition and more in the agentic condition than in the normal condition. They were asked how much they blamed the car for a crash which occurred during the scenario and they blamed the car more in the anthropomorphic condition than in the normal condition. However, they blamed the car more in the agentic condition than in the anthropomorphic condition.

Studies using a driving simulator to assess the influence of personality on driving are quite rare in personality journals. Morton and White [12] found that while people with a higher score in the fearful personality trait (FFFS) drive under stress, they have a larger braking distance at intersections. Obsessive passion relates to a strong desire to perform an activity which is not under the person's control. Harmonious passion also relates to a strong desire to perform the activity, but this desire is under control. Philippe et al. [13] found that an obsessive passion for driving correlates with aggressive behavior, while harmonious passion for driving does not.

Many studies using a driving simulator deal with the influence of cognitive or perceptual overload on driving. Active fatigue is caused by cognitive overload from overly frequent activity. Passive fatigue is caused by a long-term monotonous task. Saxby et al. [14] found that drivers with an induced active fatigue condition felt more distress than normal, while drivers in passive fatigue condition felt lower engagement than normal. Drivers with active fatigue avoided collisions more often than drivers without fatigue, while drivers with passive fatigue avoided collisions less often. Lying is more cognitively demanding than telling truth; therefore, liars have less available cognitive resources and they are prone to cognitive overload. Gawrylovicz et al. [15] found that drivers with cognitive overload induced by lying increased their speed and have a longer reaction time. Murphy and Greene [16] showed that drivers are less likely to notice an unexpected pedestrian under a high perceptual load. Blalock et al. [17] researched connections between cognitive load and the ability to remember moving and stationary objects in a simulated environment. People with no load were more accurate than people under cognitive load. People asked about stationary objects were more accurate than people asked about moving objects. People un- 
der cognitive load were worse in the accuracy of answers to questions about moving objects than people in the no-load condition. However, there was no difference between people under and without cognitive load for the questions about stationary objects. Janssen and Brumby [18] let their participants complete a set of dual-processing 30 -second drives where they had to dial a number while driving. The distance from the center of the lane was larger and the dialing was quicker in the dialing-focused tasks than in the steering-focused tasks. Watson et al. [19] researched the effect of dual tasks (driving and recalling words from memory) on memory and driving performance. Participants were slower to press the brake pedal and had a slightly elongated follow distance in the dual tasks as compared to when they should only drive. They also remembered fewer items and became increasingly reliant on reconstructive forms of memory in the dual task as compared to when they should only recall words.

Other studies concern the influence of distraction by objects on the road or people in the car. Chan et al. [20] found that drivers keep their lane better when there are taboo words on billboards along the road. Provocative content on billboards might arouse the attention of drivers, so that they drive more carefully. Garrison and Williams [21] researched the impact of distraction by conversation on visual attention and driving performance. During each drive, participants passed three types of objects: billboards, signs, and hazards (e.g., stalled or parked vehicles, etc.). Mean velocity and its variability were higher during the distraction drive. The distraction drive also showed a higher variability of steering and participants drove closer to the lane-divider line. There were fewer gazes toward objects during the distraction drive. Mean lane position varied more near hazards than near signs. Hazards received more gazes than billboards and billboards - more than signs.

Other studies analyzed differences in driving behavior among human groups. Crawley et al. [22] found no difference between pregnant and nonpregnant women while driving in a simulator. Lundqvist et al. [23] found no difference in driving performance in a simulator between people after a stroke and people of a similar age who hadn't suffered stroke (although differences were found on the real road). Raw et al. [24] found a higher difference between car position and the center of the road for older drivers than for younger drivers when driving fast, although the difference was not found for slower driving.

Several other themes have also been studied. Eriksson et al. [25] researched how people estimate the speed needed to save time on a specific distance while driving. The lower speed participants overestimated the speed increase needed to save three minutes, so they drove faster. The higher speed participants underestimated the necessary speed increase so they drove slower than they should have. Tozman et al. [26] researched the relationship between flow and heart rate variability in different driving environments. They let their participants drive in three environments to induce boredom (a straight country road with no bends and no traffic), to fit the person's skills (a bendy race course without opponents, where participant should speed), and to create anxiety (a very bendy race with nine highly skilled opponents). The flow was higher for 
the fit condition than for the anxiety condition and also higher for the anxiety condition than for the boredom condition. The increase in task difficulty decreased both high-frequency and low-frequency components of heart rate variability. The low-frequency component was a predictor of flow in the anxiety and fit conditions, and the high-frequency component only in the anxiety condition. Antonson et al. [27] researched the effect of the surrounding landscape on driving behavior. Drivers drove in a simulator through three types of roadside environments: open, forested, and varied. The lowest speed was for the varying landscape, higher for the forested landscape, and the highest for the open landscape. Drivers in the open landscape drove more to the right than in the forested landscape. Steering wheel grasp frequency was higher for the open landscape than for the forested landscape.

\section{Analysis of reviewed articles}

The tables below contain an analysis concerning the types of driving simulation that were used in the selected articles (see table 1), and what the sample sizes and the observed outcome of participants' performance in the simulator drives used in the 27 reviewed studies (see table 2).

$\mathrm{T}$ able 1

Types of driving simulation used in the reviewed studies

\begin{tabular}{|c|c|c|}
\hline Fidelity & Driving simulation & Studies \\
\hline High fidelity & $\begin{array}{l}\text { Realistic driving simulator (car- } \\
\text { like) with projection on large } \\
\text { film screens (or cylindrical } \\
\text { screen) providing view of at } \\
\text { least } 180^{\circ} \text { and rear-mirrors }\end{array}$ & $\begin{array}{l}\text { Antonson et al. [27]; Blalock et al. } \\
\text { [17]; Conner et al. [6]; Elliot et al. } \\
\text { [7]; Garrison and Williams [21]; } \\
\text { Lundqvist et al. [23]; Murphy and } \\
\text { Greene [16]; Waytz et al. [11]; } \\
\text { Gaspar et al. [10] }\end{array}$ \\
\hline \multirow{5}{*}{ Medium fidelity } & $\begin{array}{l}\text { Car-like cabin with projection } \\
\text { on one screen in front of the car }\end{array}$ & Philippe et al. [13] \\
\hline & $\begin{array}{l}\text { Driver seat with a dashboard, } \\
\text { steering wheel, and pedal, three } \\
\text { large screens with a total view } \\
\text { of } 120^{\circ}\end{array}$ & $\begin{array}{l}\text { Crawley et al. [22]; Tozman et al. } \\
\text { [26] }\end{array}$ \\
\hline & $\begin{array}{l}\text { Car-like cabin, projection on } \\
\text { three displays providing a view } \\
\text { of } 180^{\circ}\end{array}$ & Eriksson et al. [25] \\
\hline & $\begin{array}{l}\text { Driving simulator (not car-like) } \\
\text { with realistic driving controls and } \\
\text { shown on three large displays } \\
\end{array}$ & $\begin{array}{l}\text { Brewster et al. [8]; Janssen et al. [9]; } \\
\text { Lambert et al. [1]; Watson et al. [19]; } \\
\text { Chan et al. [20]; Saxby et al. [14] }\end{array}$ \\
\hline & $\begin{array}{l}\text { Driver seat in front of a large } \\
\text { screen }\end{array}$ & $\begin{array}{l}\text { Raw et al. [24]; Jackson and } \\
\text { Blackman [3]; Gawrylowicz et al. } \\
{[15]}\end{array}$ \\
\hline Low fidelity & $\begin{array}{l}\text { Driving in a video/computer } \\
\text { game or simulation projected on } \\
\text { one display }\end{array}$ & $\begin{array}{l}\text { Fischer et al. [4]; Janssen and } \\
\text { Brumby [18]; Morton and White } \\
\text { [12]; Shepherd et al. [5]; Taubman } \\
\text { Ben-Ari [2] }\end{array}$ \\
\hline
\end{tabular}


T a ble 2

\section{Number of participants driving in simulation and dependent variables measured} in reviewed studies

\begin{tabular}{|c|c|c|}
\hline Study & $\begin{array}{c}\text { Number of } \\
\text { participants } \\
\text { in simulation } \\
\end{array}$ & Observed outcome \\
\hline Antonson et al. [27] & 18 & $\begin{array}{l}\text { Speed, lateral vehicle position in the lane, and } \\
\text { maximum and mean variations in the frequency } \\
\text { of steering wheel grasping }\end{array}$ \\
\hline Blalock et al. [17] & $28(+5 \mathrm{M})$ & Ability to remember objects around the road \\
\hline Brewster et al. [8] & 139 & $\begin{array}{l}\text { Percentage of critical situations when the driver } \\
\text { exceeded the speed limit }\end{array}$ \\
\hline Chan et al. [20] & $30(+9 \mathrm{E})$ & $\begin{array}{l}\text { Mean driving speed, root-mean-square error } \\
\text { [RMSE] of the driver's lateral lane position with } \\
\text { respect to the roadway dividing line, RMSE of } \\
\text { how fast the driver turns the steering wheel }\end{array}$ \\
\hline Conner et al. [6] & 178 & $\begin{array}{l}\text { Percentage of time spent driving at } 10 \mathrm{mph} \text { or } \\
\text { more in excess of the speed limit }\end{array}$ \\
\hline Crawley et al. [22] & $30(+2 \mathrm{M})$ & $\begin{array}{l}\text { Reaction time, brake time until } 100 \text { Newtons of } \\
\text { pressure after signal to brake, time until participant } \\
\text { started the maneuver, the maneuver time, gap-size } \\
\text { accepted, time to collision, number of collisions }\end{array}$ \\
\hline Elliot et al. [7] & 150 & $\begin{array}{l}\text { Mean driving speed, proportion of the distance } \\
\text { with speed limit exceeded by } 10 \%\end{array}$ \\
\hline Eriksson et al. [25] & 12 & Time gain after being instructed to drive faster \\
\hline Fischer et al. [4] & 60 & $\begin{array}{l}\text { Maximum speed, time to accelerate to } 160 \mathrm{kph} \text {, } \\
\text { total driving time, number and type of accidents }\end{array}$ \\
\hline Garrison and Williams [21] & 20 & $\begin{array}{l}\text { Mean velocity, lane offset, steering angle, brake } \\
\text { pressure, gazes towards objects }\end{array}$ \\
\hline Gaspar et al. [10] & 24 & $\begin{array}{l}\text { Collisions per merging event, collisions per } \\
\text { braking event, percentage of correct exits taken, } \\
\text { mean and standard deviation of speed, follow- } \\
\text { ing distance, maintaining lateral lane, recogni- } \\
\text { tion memory for } 24 \text { road signs }\end{array}$ \\
\hline Gawrylowicz et al., [15] & 90 & Speed, reaction time when seeing pedestrian \\
\hline Jackson and Blackman [3] & 14 & $\begin{array}{l}\text { Average speed, average speed when car is not } \\
\text { stopped, average speed at corners, amount of } \\
\text { time spent driving over } 40 \mathrm{kph} \text { and over } 60 \mathrm{kph} \text {, } \\
\text { maximum speed, number of times the steering } \\
\text { wheel passed through the zero-degree position, } \\
\text { time spent over the central line }\end{array}$ \\
\hline Janssen and Brumby [18] & 14 & Distance from the center of the lane \\
\hline Janssen et al. [9] & 24 & $\begin{array}{l}\text { Time of reaction to the leading car's speed } \\
\text { change, whether driver responded to speed } \\
\text { changes with the same pace as the leading car, } \\
\text { distance from the leading car }\end{array}$ \\
\hline \begin{tabular}{|l} 
Lambert et al. [1] \\
\end{tabular} & $39(+21 \mathrm{M})$ & Gollowing distance, brake reaction time \\
\hline Lundqvist et al. [3] & 60 & $\begin{array}{l}\text { Speed, lateral position, reaction time, time to } \\
\text { collision and distance to collision }\end{array}$ \\
\hline Morton and White [12] & 71 & $\begin{array}{l}\text { Meters from sign when signal first detected, } \\
\text { meters from hazard when brake first applied, }\end{array}$ \\
\hline
\end{tabular}




\begin{tabular}{|l|c|l|}
\hline \multicolumn{1}{|c|}{ Study } & $\begin{array}{c}\text { Number of } \\
\text { participants } \\
\text { in simulation }\end{array}$ & \multicolumn{1}{|c|}{ Observed outcome } \\
\hline & 42 & $\begin{array}{l}\text { force applied to brake pedal, average speed, } \\
\text { speed variability, standard deviation of wheel } \\
\text { movement }\end{array}$ \\
\hline Murphy and Greene [16] & $\begin{array}{l}\text { Ability to notice object different from the pre- } \\
\text { vious drive }\end{array}$ \\
\hline Philippe et al. [13] & 28 & $\begin{array}{l}\text { Self-report questionnaire assessing driver's } \\
\text { aggressive feelings, judges' assessment of ag- } \\
\text { gressiveness of driver's behavior on a vide- } \\
\text { otaped session }\end{array}$ \\
\hline Raw et al. [24] & $\begin{array}{l}\text { Difference between car position and the middle } \\
\text { of the road }\end{array}$ \\
\hline Saxby et al. [14] & 108,168 & $\begin{array}{l}\text { Scales assessing participant feelings before and } \\
\text { after a drive, ability to avoid a crash in an in- } \\
\text { duced collision situation }\end{array}$ \\
\hline Shepherd et al. [5] & 199,103 & Maximum speed, number of accidents \\
\hline Taubman Ben-Ari et al. [2] & 56,108 & $\begin{array}{l}\text { Average speed as assessed by judges watching } \\
\text { videotape }\end{array}$ \\
\hline Tozman et al. [26] & 18 & Interbeat intervals of the heart, feeling of flow \\
\hline Watson et al. [19] & $23(+15 \mathrm{M})$ & $\begin{array}{l}\text { Brake-reaction time, distance following the } \\
\text { leading car }\end{array}$ \\
\hline Waytz et al. [11] & 100 & $\begin{array}{l}\text { Perceived anthropomorphism of the car, trust in } \\
\text { car, blaming car for responsibility for crash }\end{array}$ \\
\hline
\end{tabular}

Note. $\mathrm{M}$ - removed from study due to motion sickness; E - excluded from analyses

\section{Discussion}

Psychological disciplines differ by their narrow focus (details and mechanisms) or their wide focus (systems and larger processes). Cognitive psychology and experimental disciplines are narrower, social psychology is broader [28]. The narrower disciplines more often apply experimental design in research, while the broader disciplines apply survey research design. As we can see, six of the seven examined studies with a sample larger than 100 people belong to the area of social or personality psychology. It seems that the studies in the areas of social and personality psychology keep larger samples and the studies in other areas keep smaller samples even when they use a similar research design.

The difference between social psychology and other disciplines could also be seen when assessing the type of driving simulation used. The largest number of studies (10) used high-fidelity simulation, while five studies used some type of a computer game. Four of five studies that used the lowest quality simulation belong to social or personality psychology. For broader psychological disciplines details are not such important. Therefore, it is not necessary to have realistic simulation when conducting research. Such acceptance of imprecision would be less acceptable in more narrow disciplines.

Driving simulation is an interaction between human and environment. As such, it allows observing two kinds of measures: those measuring something that happened in the environment during the simulation and those measuring human ex- 
perience. The first type of variable in the reviewed studies - the environment-based variables - contains speed, the lateral position of the vehicle or the distance from other cars, steering wheel usage, reaction time, the number of collisions, gazes toward objects, and brake pressure. The second type of variable - human experiencebased variables - contains the quality of memory recognition, the change of participant's feelings after the drive, the aggressiveness of the driver's behavior, and the driver's opinion about the car.

Another question we may ask is: in which cases it was necessary to use a driving simulation when conducting the research in the analyzed articles. First, many of the articles researched driver's behavior in a collision situation [11] or used the number of collisions as a measure ([4, 10, 14 and 22]). This would not be possible in real-life conditions. Second, other articles studied the following distance behind a leading car ([1] and [19]) or reaction to provocations from other drivers [8]. Conducting such experiments in the real environment would be possible, but there would be a high risk for an accident. Third, a study like [16] - showing driver repeatedly certain static situation in a traffic -would be impossible to conduct with the same precision in the real environment, where it is not possible to reach the same level of control over the intervening variables.

Driving simulators are, therefore, necessary for psychological research in some conditions. When a researcher wants to research a behavior which would be illegal (e.g., an accident), a driving simulator is an option. A driving simulator is also an option when a researcher wants to have an environment where they might control the intervening variables. And driving simulators might be the safer option when the researcher wants to study risky driving behavior.

\section{Conclusion}

The use of driving simulators in articles published in psychological journals has been analyzed in this text. First, the content of the selected articles was described. The type of driving simulation used, the measured outcome of the driving simulation, and the sample sizes were also analyzed. Driving simulator usage is quite rare in (non-transportation) psychological journals. It could be a very valuable source for realistic psychological research because it is possible to study things like accidents or reactions to other driver's provocations, which would otherwise not be possible to study. Nevertheless, researchers do not use driving simulators because realistic research is not perceived as necessary in some parts of psychology.

The current study provides two suggestions for future researchers. First, highfidelity driving simulators seem to be less used in social psychology. Simulations using devices like a computer game or PlayStation are accepted in the field. Researchers who work with realistic simulators might consider conducting some research that would be publishable in social psychological journals. Such research might contain the study of other people's influence on driving performance, social norms and stereotype influence, driving while having an interpersonal conflict with another person in the car, and similar themes. Second, simulator studies might also use more human experience-based measures (e.g. the feelings of drivers in different situations). 


\section{Acknowledgements}

This article was produced with the financial support of the Ministry of Education, Youth and Sports within the National Sustainability Programme I, project of Transport R\&D Centre (LO1610), on the research infrastructure acquired from the Operation Programme Research and Development for Innovations (CZ.1.05/2.1.00/03.0064).

\section{References}

1. Lambert, A.E., Watson, J.M., Stefanucci, J.K., Ward, N., Bakdash, J.Z. \& Strayer, D.L. (2016) Stereotype threat impairs older adult driving. Applied Cognitive Psychology. 30. pp. 22-28. DOI: $10.1002 / a c p .3162$

2. Ben-Ari, O.T., Florian, V. \& Mikulincer, M. (2000) The impact of mortality salience on reckless driving: A test of terror management mechanisms. Journal of Personality and Social Psychology. 76. pp. 35-45. DOI: 10.1037/0022-3514.76.1.35

3. Jackson, J.S.H. \& Blackman, R. (1994) A driving-simulator test of Wilde's risk homeostasis theory. Journal of Applied Psychology. 79. pp. 950-958. DOI: 10.1037/00219010.79.6.950

4. Fischer, P., Guter, S. \& Frey, D. (2008) The effects of risk-promoting media on inclinations toward risk taking. Basic and Applied Social Psychology. 30. pp. 230-240. DOI: 10.1080/01973530802375029

5. Shepherd, J.L., Lane, D.J., Tapscott, R.L. \& Gentile, D.A. (2011) Susceptible to social influence: Risky "driving" in response to peer pressure. Journal of Applied Social Psychology. 41. pp. 773-797. DOI: 10.1111/j.1559-1816.2011.00735.x

6. Conner, M., Lawton, R., Parker, D., Chorlton, K., Manstead, A.S.R. \& Stradling, S. (2007) Application of the theory of planned behaviour to the prediction of objectively assessed breaking of posted speed limits. British Journal of Psychology. 98. pp. 429-453. DOI: 10.1348/000712606X133597

7. Elliot, M.A., Armitage, Ch.J. \& Baughan, Ch.J. (2007) Using the theory of planned behaviour to predict observed driving behaviour. British Journal of Social Psychology. 46. pp. 69-90. DOI: 10.1348/014466605X90801

8. Brewster, S.E., Elliot, M.A., McCartan, R., McGregor, B. \& Kelly, S.W. (2016) Conditional or Unconditional? The Effects of Implementation Intentions on Driver Behavior. Journal of Experimental Psychology: Applied. 22. pp. 124-133.DOI: 10.1037/xap0000072

9. Janssen, Ch.P., Iqbal, S.T. \& Ju, Y.-Ch. (2014) Sharing a driver's context with a caller via continuous audio cues to increase awareness about driver state. Journal of Experimental Psychology: Applied. 20. pp. 270-284. DOI: 10.1037/xap0000020

10. Gaspar, J.G., Street, W.N., Windsor, M.B., Carbonari, R., Kaczmarski, H., Kramer, A.F. \& Mathewson, K.E. (2014) Providing Views of the Driving Scene to Drivers' Conversation Partners Mitigates Cell-Phone-Related Distraction. Psychological Science. 25. pp. 2136-2146. DOI: 10.1177/0018720809337503

11. Waytz, A., Heafner, J. \& Epley, N. (2014) The mind in the machine: Anthropomorphism increases trust in an autonomous vehicle. Journal of Experimental Social Psychology. 52. pp. 113-117. DOI: 10.1016/j.jesp.2014.01.005

12. Morton, R.D. \& White, M.J. (2016) Revised reinforcement sensitivity theory: The impact of FFFS and stress on driving. Personality and Individual Differences. 54. pp. 57-63. DOI: $10.1016 /$ j.paid.2012.08.005

13. Philippe, F.L., Vallerand, R.J., Richer, I., Vallieres, E. \& Bergeron, J. (2009) Passion for driving and aggressive driving behavior: A look at their relationship. Journal of Applied Social Psychology. 39. pp. 3020-3043. DOI: 10.1111/j.1559-1816.2009.00559.x 
14. Saxby, D.J., Matthews, G., Warm, J.S., Hitchcock, E.M. \& Neubauer, C. (2013) Active and Passive Fatigue in Simulated Driving: Discriminating Styles of Workload Regulation and Their Safety Impacts. Journal of Experimental Psychology: Applied. 19. pp. 287-300. DOI: $10.1037 / \mathrm{a} 0034386$

15. Gawrylowicz, J., Fairlamb, S., Tantot, E., Qureshi, Z., Redha, A., \& Ridley, A.M. (2016) Does Practice Make the Perfect Liar? The Effect of Rehearsal and Increased Cognitive Load on Cues to Deception. Applied Cognitive Psychology. 30. pp. 250-259. DOI: 10.1002/acp.3199

16. Murphy, G. \& Greene, C.M. (2016) Perceptual load induces inattentional blindness in drivers. Applied Cognitive Psychology. 30. pp. 479-483. DOI: 10.1002/acp.3216

17. Blalock, L.D., Sawyer, B.D., Kiken, A., Gutzwiller, R.S., McGill, C.L. \& Clegg, B.A. (2014) Cognitive load while driving impairs memory of moving but not stationary elements within environment. Journal of Applied Research in Memory and Cognition. 3. pp. 95-100. DOI: 10.1016/j.jarmac.2014.04.006

18. Janssen, Ch.P. \& Brumby, D.P. (2010) Strategic adaptation to performance objectives in a dual-task setting. Cognitive Science. 34. pp. 1548-1560. DOI: 10.1111/j.15516709.2010.01124.x

19. Watson, J.M., Memmott, M.G., Moffitt, Ch.C., Coleman, J., Turrill, J., Fernández, Á. \& Strayer, D.L. (2016) On working memory and a productivity illusion in distracted driving. Journal of Applied Research in Memory and Cognition. 5. pp. 445-453. DOI: 10.1016/j.jarmac.2016.06.008

20. Chan, M., Madan, Ch.R. \& Singhal, A. (2016). The effects of taboo-related distraction on driving performance. Acta Psychologica. 168. pp. 20-26. DOI: 10.1016/j.actpsy.2016.03.010

21. Garrison, T.M. \& Williams, C.C. (2013) Impact of relevance and distraction on driving performance and visual attention in a simulated driving environment. Applied Cognitive Psychology. 27. pp. 396-405. DOI: 10.1002/acp.2917

22. Crawley, R., Grant, S. \& Hinshaw, K. (2008) Cognitive changes in pregnancy: Mild decline or societal stereotype? Applied Cognitive Psychology. 22. pp. 1142-1162. DOI: 10.1002/acp. 1427

23. Lundqvist, A., Gerdle, B. \& Rönnberg, J. (2000) Neuropsychological aspects of driving after a stroke - in the simulator and on the road. Applied Cognitive Psychology. 14. pp. 135-150. DOI: 10.1002/(SICI)1099-0720(200003/04)14:2<135::AID-ACP628>3.0.CO;2-S

24. Raw, R.K., Kountouriotis, G.K., Mon-Williams, M. \& Wilkie, R.M. (2012) Movement control in older adults: Does old age mean middle of the road? Journal of Experimental Psychology: Human Perception and Performance. 38. pp. 735-745. DOI: $10.1037 / \mathrm{a} 0026568$

25. Eriksson, G., Svenson, O. \& Eriksson, L. (2013) The time-saving bias: Judgements, cognition and perception. Judgment and Decision Making. 8. pp. 492-497.

26. Tozman, T., Magdas, E.S., MacDougall, H.G. \& Vollmeyer, R. (2015) Understanding the psychophysiology of flow: A driving simulator experiment to investigate the relationship between flow and heart rate variability. Computers in Human Behavior. 52. pp. 408-418. DOI: 10.1016/j.chb.2015.06.023

27. Antonson, H., Mårdh, S., Wiklund, M. \& Blomqvist, G. (2009) Effect of surrounding landscape on driving behavior: A driving simulator study. Journal of Environmental Psychology. 29. pp. 493-502. DOI: 10.1016/j.jenvp.2009.03.005

28. Peterson, D. (2016) The depth of fields: Managing focus in the epistemic subcultures of mind and brain science. Social Studies of Science. [Online] Available from: http://journals.sagepub.com/doi/full/10.1177/0306312716663047. 
Information about the authors:

LINKOV Václav, CDV - Transport Research Centre, Brno, Czech Republic. E-mail: vaclav.linkov@hotmail.com

ZÁMEČNíK Petr, Palacký University, Department of Psychology, Olomouc, Czech Republic. E-mail: Petr.zamecnik@centrum.cz

ZAORAL Aleš, CDV - Transport Research Centre, Brno, Czech Republic. E-mail: ales.zaoral@cdv.cz

\section{ИСПОЛЬЗОВАНИЕ СИМУЛЯТОРОВ ВОЖДЕНИЯ В ПСИХОЛОГИЧЕСКОМ} ИССЛЕДОВАНИИ

Линков Вацлав, Центр транспортных исследований (Líšeňská 33a, 63600 Brno, Czech Republic). E-mail: vaclav.linkov@hotmail.com

Замечник Петр, Университет Палацкого, г. Оломоуц (Vodární 6, 77180 Olomouc, Czech Republic). E-mail: Petr.zamecnik@centrum.cz

Заорал Алеш, Центр транспортных исследований (Líšeňská 33a, 63600 Brno, Czech Republic). E-mail: ales.zaoral@cdv.cz

Ключевые слова: симулятор вождения; психология; стереотипы; отвлечение внимания; когнитивная перегрузка.

Симуляторы вождения - важный исследовательский инструмент, помогающий оценить поведение водителей. В статье рассматриваются изученные при помощи симуляторов вождения вопросы, описанные в психологических журналах, определяется, какие симуляторы могут быть использованы, сколько участников необходимо для публикации подобного исследования, а также параметры, которые могут быть использованы. Статья может быть полезна специалистам в области психологии, планирующим провести исследование при помощи симулятора вождения. 